\title{
THE GLACIERS OF JOSTEDALSBREEN
}

\author{
By R. FINSTERWALDER \\ (Institut für Photogrammetrie, Topographie und Allgemeine Kartographie, Technische \\ Hochschule, München)
}

A RECENT publication by my colleague, Dr. W. Pillewizer, describes glaciological work carried out on Jostedalsbreen in the summer of 1937 by himself, Dr. W. Evers and myself. ${ }^{1}$ Photogrammetric maps and measurements made of glacier speeds showed that two distinct types of glaciers flowing from the accumulation area existed.*

(I) Long valley glaciers. These were not interrupted by ice falls and followed distinct valleys which could be traced far up into the ice cap.

(2) Short, steep glaciers. These tumbled over in ice falls over precipices or down steep gullies from the ice cap. The ice from these collected in short, flat tongues.

The flow of the long glaciers was investigated on Nigardsbreen and Tunsbergdalsbreen, the two largest ice streams of the system (see Fig. I, below left). Maps to a scale of $I: 25,000$ were also made of these two glaciers.
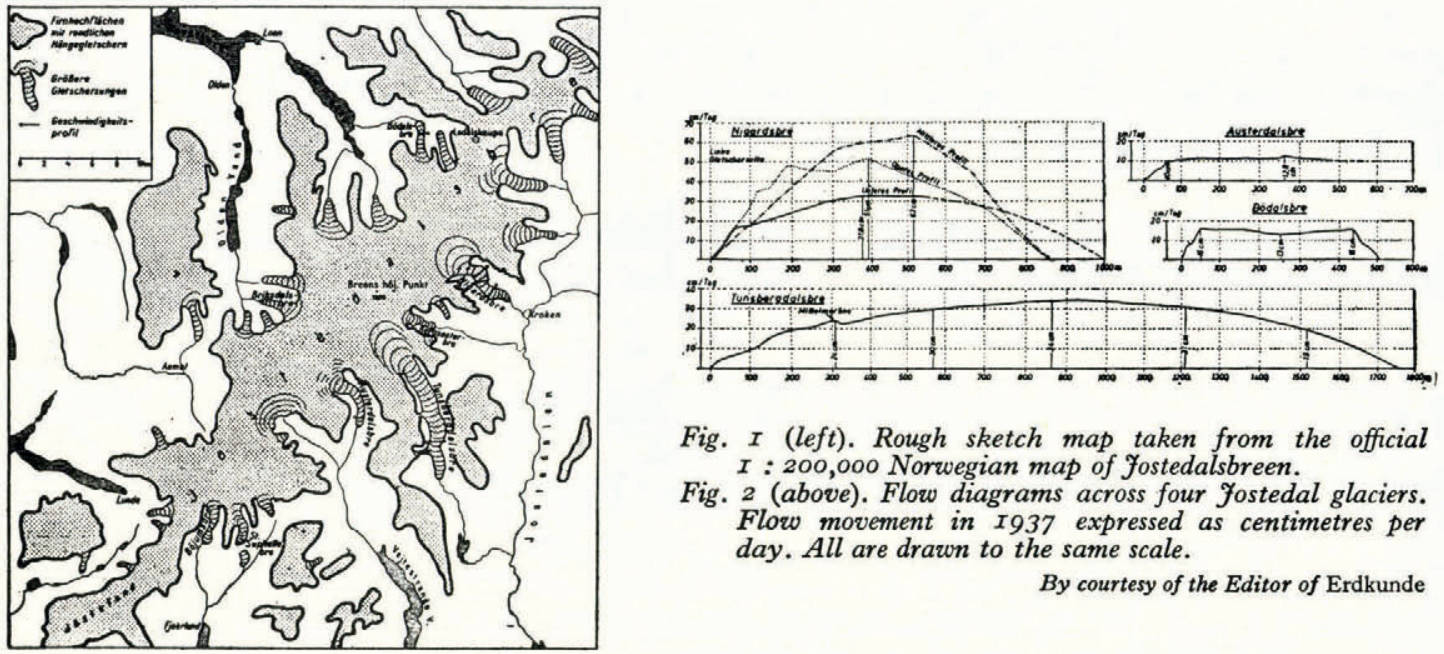

Fig. I (left). Rough sketch map taken from the official I : 200,000 Norwegian map of fostedalsbreen.

Fig. 2 (above). Flow diagrams across four Fostedal glaciers. Flow movement in 1937 expressed as centimetres per day. All are drawn to the same scale.

By courtesy of the Editor of Erdkunde

Flow measurements were made along three transverse lines on Nigardsbreen and along one line on Tunsbergdalsbreen. The former glacier is about $\mathbf{~ k m}$. broad, the latter nearly double this figure. Measurements were also made across the flat tongues of Austerdalsbreen and Bödalsbreen. The surface cross sections are shown in the flow diagrams in Fig. 2 (above right) in which the speed per day is plotted against the distance from the glacier margins.

It will be seen that in the long glaciers the rate of flow increases gradually and more or less uniformly in a parabolic curve, whereas in the short glaciers the maximum speed is reached very close to the glacier bank and thereafter the whole of the central zone of the glacier moves at a more or less uniform rate.

\footnotetext{
" Professor Finsterwalder distinguishes between the glaciers flowing from Jostedalsbreen and those from the Greenland ice cap. He assumes that the latter lies in a vast hollow "filled with ice to a depth of some 2,000 m." The Jostedal ice cap, he believes, lies mainly in a series of isolated basins. He therefore differentiates between the glaciers flowing from the Greenland ice cap which are typically of the "outflow" type and those of Jostedalsbreen of which many appear to be more of the "valley" type.-Ed.
} 
The flow of the long glaciers is typically a regular, streaming movement, as has been described by us elsewhere. 2 The flow of the short glaciers is much more akin to the Block-Schollen flow which we have also described. The chief characteristic of this form of motion is the rapid increase of speed in a narrow marginal zone and the uniform speed in a wide central band, so that the glacier moves forward as a single homogeneous block. But it must be noted that in those ice streams in which this form of flow has been recognized a speed of one metre and more a day has been the rule. The speed at the tongues of these short Jostedalsbreen glaciers (12-16 cm./day) is doubtless not fast enough to cause this form of flow, but it is reasonable to assume that it develops in the $1000 \mathrm{~m}$. high ice falls and that the short flat tongues are not long enough for streaming flow to become re-established.

It should also be noted that the large glaciers like Tungsbergdalsbreen and Nigardsbreen have large accumulation areas whose beds seem to merge into their lower valleys smoothly without considerable sharp downward change of gradient. Even the medium-sized glaciers like Austerdalsbreen and Böjumsbreen possess accumulation areas, but in these cases the flat firn basin changes into a steep ice fall. Conspicuously different are some smaller glaciers which lie as "glacier caps" on slightly domed eminences from which they flow off into very small tongues.

Contrary to previous belief the rock bed of Jostedalsbreen consists mainly of a series of isolated firn basins flowing outwards and is not a domed plateau with ice flowing off evenly in all directions. The surface of the ice in the firn area reflects this structure of the bed very clearly.

The thickness of ice of Tungsbergdalsbreen can be calculated by the Lagally formula to be about $320 \mathrm{~m}$. deep at the place where the speed was measured (inclination $7^{\circ}$ ) and $310 \mathrm{~m}$. in the middle profile of Nigardsbreen $\left(13^{\circ}\right)$. These data are not sufficient to enable us to calculate the ice economy, since the measurements were made too far below the firn line. Between the points measured to the firn line and above the active ablation is the determining point and data are not yet available for its calculation.

It would be of the greatest interest to repeat the flow measurements because the glaciers have melted considerably since 1937 . As a result the flow will have slackened considerably. It is highly desirable that such new speed measurements should be made close to the firn line and in some glaciers, for instance Tunsbergdalsbreen, this would be easy. They would provide a valuable basis for calculating the ice economy.

\section{R E F E R E N C E S}

1. Pillewizer, W. Bewegungsstudien an Gletschern der Jostedalsbre in Südnorwegen. Erdkunde, Bd. 4, Ht. 3-4, 1950, p. $201-06$.

2. See, for instance: Finsterwalder, R. Some comments on glacier flow. Fournal of Glaciology, Vol. 1, No. 7, p. 383 . Finsterwalder, R., and Pillewizer, W. Photogrammetric studies of glaciers in high Asia. The Himalayan fournal, Vol. 2, 1939, p. 107-13.

\section{GLACIER FLUCTUATION IN THE SWISS ALPS, I $95^{\circ *}$}

GLACIER recession continued at an increased rate during 1950 , the figures for 1949 and $195^{\circ}$ being:

$$
\begin{array}{cccccc} 
& & & \text { Advance } & \text { Stationary } & \text { Retreat } \\
1949 & \ldots & \ldots & 5 \% & 2 \% & 93 \% \\
1950 & \because & \ldots & 4 \% & 0 \% & 96 \%
\end{array}
$$

A detailed report on the fluctuation of European glaciers (French, Swiss, Italian, Austrian, Scandinavian with Iceland) from 1935 to 1946 appears in The Transactions of the International Association of Hydrology (I.U.G.G.), Oslo, Vol. 2, 1948, p. 233-6r.

\footnotetext{
- Advance report of the 1950 glacier measurements of the Commission Helvétique des Glaciers communicated by Dr. P-L. Mercanton.
} 